\title{
Anticipated versus Inferred Politeness
}

Michael Haugh

\begin{abstract}
:
A number of researchers have recently argued that politeness is not always inferred in the form of an implicature as claimed by Brown and Levinson (1987), but rather can be anticipated by addressees when it involves expected behaviour. The distinction between anticipated and inferred politeness is thus an important area for further development of politeness theory. In this paper, the way in which the notion of 'expectations' is related to politeness is first considered, before outlining the distinction between anticipated and inferred politeness in some detail. It is then argued that discourse politeness theory (Usami, 1998, 2001a, b, 2002) shows greater promise for deepening our understanding of this distinction than the proposals made thus far by relevance theorists. It is concluded that any investigation of the distinction between anticipating and inferring politeness must ultimately be grounded in empirical studies of politeness phenomena.
\end{abstract}

Politeness has been the subject of an enormous amount of research in the past twenty years, but it has also generated considerable controversy. Brown and Levinson's (1987) face-saving view of politeness in particular has stimulated a prolific amount of discussion. Various aspects of Brown and Levinson's theory have received attention, but in recent times their claim that politeness is something that is communicated by means of an implicature has come under scrutiny.

Brown and Levinson assume that for politeness to arise in interaction, a 'polite intention' must be attributed to the speaker by the addressee (Brown 1995: 169, 2001: 11623; Brown and Levinson 1987: 95). This attribution by inference to the speaker of an intention to be polite constitutes a (particularised) implicature:

"Polite utterances are not necessarily communicating 'real' feelings about another's social persona, but expressing contextually-expected concern for face. This concern is an 'implicature', an inference of polite intentions, not a feature inextricably attached to particular linguistic forms." (Brown 2001: 11623, author's original emphasis) 
A number of researchers, however, have argued that this assumption is counter-intuitive. They argue that politeness is generally not inferred as an implicature, as it is usually expected by interactants, and thus is not noticed (Escandell-Vidal, 1998; Jary, 1998a; Fraser, 1990, 1999; Matsui, 2001; Terkourafi, 2001a, 2001b; Zegarac, 1998). This kind of politeness is termed "anticipated politeness" by Fraser (1999), in order to contrast it with Brown and Levinson's view of politeness as inferred. While a number of researchers argue that politeness is only anticipated and thus is never inferred (Escandell-Vidal, 1998; Fraser, 1999), ${ }^{1}$ others have assumed that although politeness is primarily anticipated, it may also be inferred in the form of an implicature (Jary, 1998a: 6-7; Matsui 2001: 52; Terkourafi, 2001a: 179, 2001b: 120-127; Zegarac 1998: 353-354). In other words, there are two main ways in which politeness is communicated: it may be anticipated or it may be inferred.

In this paper, the way in which politeness arises relative to situation-specific social norms is first discussed to illustrate how the expectations that underlie anticipated and inferred politeness are distinct from adherence to social norms or conventions. The distinction between anticipated and inferred politeness is then considered in more detail in the second section, contrasting it with other distinctions that have been drawn in politeness theory. In the third section, it is briefly argued that relevance theoretic explanations of politeness do not provide a solid basis for furthering our understanding of the notions of anticipated and inferred politeness. In the final section it is suggested that discourse politeness theory (Usami 1998, 2001a, 2001b, 2002), has greater potential for future investigation of this important distinction in politeness theory.

\section{Politeness and social norms ${ }^{2}$}

Politeness involves people showing they think well of others or showing they don't think more highly of themselves than they should. In Japanese, for example, this may involve showing one respects the social position of others (or that one does not respect one's own social position too much). In English, on the other hand, it may involve showing one respects the right of others to be free from imposition (or that one does not think too highly of one's own right to be free from imposition). What constitutes showing one thinks well of others (or at least showing one does not think badly of others), and showing one does not think 
more highly of oneself than one should, involves a number of aspects that vary across different cultures. In other words, politeness is a culture-sensitive phenomenon (Alymursy and Wilson, 2001; Janney and Arndt, 1993; Lee-Wong, 2002; Nwoye, 1989).

On the basis of utterances which show a speaker thinks well of others (or at least not badly of others), addressee's form perceptions of how others evaluate them. And addressee's also form perceptions of how others evaluate themselves, on the basis of utterances which show a speaker does not think more highly of him/herself than he should. When the addressee's perceptions lie within the thresholds of appropriateness as dictated by social norms (Eelen, 2001; Selnick, 2002), various types of politeness arise. These social norms vary according to the situation and also across individuals. In other words, politeness is situation-sensitive (Matsumoto, 1989; Pan, 2000), and perceptions of it vary across native speakers of a language (Eelen, 2001).

For example, politeness may arise in (New Zealand) English upon receiving an invitation to lunch from a colleague in a university department. This colleague, whom I have only just met, shows he approves of me through this invitation. On the basis of his invitation, I may form the perception that my colleague approves of me, and since this degree of approval lies within the range of what might be expected according to social norms in this situation, politeness arises.

People are also concerned about what one shows one thinks of oneself in front of others, and this concern for what we show we think of ourselves is related to evaluations of politeness. For example, in (New Zealand) English if someone praises my work at a departmental meeting, I may respond to this compliment by saying that much of the work was due to another colleague with whom I collaborated. By highlighting the contribution of my colleague I show that I do not think too highly of my ability as a researcher. If on the basis of my response to the compliment, the other person thinks that I do not think too highly of myself, politeness may arise, because being modest about one's work lies within the range of what is expected according to the norms of that kind of situation.

Politeness thus always arises relative to some kind of situation-specific social norms. These norms are essentially expectations about what people should show they think of others, or what people should show they think of themselves. In other words, these social norms are expectations in the sense of thinking something is necessary. In this way, whether a particular behaviour is regarded 
as polite or not, depends on its perception relative to what one thinks is necessary for people to show they think of someone else, or think of themselves. If one thinks that 'what a person shows they think of others' is the same or better than 'what they should show they think of others', politeness arises. And if one thinks that 'what a person shows they think of themselves' is the same or worse than 'what they should show they thinks of themselves', politeness also arises. Naturally, there is some variation across speakers as to what they think is necessary to show one thinks of others and oneself, but if politeness is to arise (as opposed to dispute about politeness), there must be some consensus about the social norms for that particular situation.

However, there is also another kind of expectation that influences the way in which politeness arises. While expectations may involve thinking something is necessary (to occur), they may also involve thinking something is likely to occur. In other words, expectations as estimations of the probability that a particular behaviour will occur. It is expectation in this second sense that is fundamental to the way in which politeness is communicated: whether it is anticipated or it is inferred.

\section{The distinction between anticipated and inferred politeness}

The distinction between anticipated and inferred politeness is predicated on the notion of expectation as an estimation of the probability that a certain behaviour will occur. In other words, what the addressee thinks the speaker will most likely show the speaker thinks of the addressee (or what the addressee thinks the speaker will most likely show the speakers thinks of the speaker). If we expect a certain behaviour to occur that does indeed occur, and this behaviour gives rise to politeness, then politeness is anticipated. On the other hand, if we are not expecting a certain behaviour to occur that nevertheless does occur, and this behaviour gives rise to politeness, then this politeness must be inferred. In other words, politeness is anticipated when the behaviour giving rise to politeness is expected, while it is inferred when the behaviour giving rise to politeness is not expected.

Politeness which is anticipated arises, and thus is unnoticed, when the linguistic form or pragmatic strategy is conventionally used in a particular situation 
(Terkourafi 2001a: 179, 2001b: 120-127; Zegarac 1998: 353). In other words, we expect that someone will show they think well of others, or do not think more highly of themselves than they should (thereby giving rise to politeness), because this particular linguistic form or strategy is commonly used in that kind of situation.

In example (1), the utterance is conventionalised in (British) English for conveying a request such as (2).

(1) (John is a guest addressing his host at during a dinner party at the latter's house)

John: I was wondering if it is OK to open some windows?

(2) The speaker wants some windows opened. (Terkourafi 2001a: 179)

Terkourafi claims that politeness is a part of the conventional meaning of the utterance in (1) in this context. ${ }^{3}$

"Based on his/her prior experience in similar communicative situations, s/he will already hold a belief that, roughly, 'uttering (something like) (1) when one is a guest at another's house and one wishes to perform 'something like) the request in (2) in English is polite'. Based on this belief, upon the speaker's uttering (1) in this situation, the addressee will form the further belief that the speaker is polite. Since politeness as a perlocutionary effect consists in the addressee holding this further belief, politeness will now have been achieved without the recognition of whatever intention the speaker may have had. That is, it will have now been not implicated, but anticipated: requiring no inferencing to be achieved, it passes unnoticed." (ibid: 180).

In another example of anticipated politeness, when meeting colleagues at the department in which I work it is normal to greet each other in a formulaic sequence such as illustrated in example (3).

(3) Jane: Hi, how are you?

Bill: I'm fine, how are you?

Jane: Good thanks.

Since the main function of Jane's first utterance is not really to inquire about the hearer's well-being as such, but rather to simply show the willingness of Jane to engage in social interaction with Bill, it is an example of phatic communication, which also gives rise to politeness. ${ }^{4}$ The politeness arising from this utterance, however, is generally not noticed. In fact, it is only noticed in its absence, because Bill expects that Jane will say something like this. That is to say, if Jane 
does not say $\mathrm{Hi}$, how are you? when bumping into Bill, although it might simply be interpreted as tiredness on Jane's part, it could also be interpreted as a lack of concern for him, which could give rise to perceptions of impoliteness. The politeness that arises in this kind of example is thus anticipated, because Bill expects Jane will show she is willing to engage in social interaction with him by saying something like $\mathrm{Hi}$, how are you?

Politeness is inferred (by means of an implicature) "when the expression used by the speaker is not conventionalised for some use" (ibid: 175). Terkourafi (2001a) argues that in (British) English the utterance in example (4) gives rise to the implicature that the speaker is being polite in the process of drawing the (particularised) implicature that the speaker wants the hearer to make it 'not-hot' for the speaker. ${ }^{5}$

(4) (A is a guest addressing his host during a dinner party at the latter's house)

A: It's hot in here.

Implies: The speaker is being polite [in uttering (4)]

Implies: The speaker wants me to somehow make it 'not-hot' for him/her.

(ibid: 177)

In this example, politeness is not anticipated, because the hearer does not necessarily expect that speaker will show he thinks well of him or her by implying a request in this manner, so it must therefore be inferred.

Examples of inferred politeness can also be found in Japanese. In example (5) the speaker's intention to be polite is inferred directly from what the teacher says.

(5) (A teacher says to a student...)

Teacher: Kono eibun essei, naiyoo totemo ii kara, ato wa this English essay, contents very good so, afterwards Topic

bunpoo to tsuzuri no mondai dake ne.

grammar and spelling of problem only Mood

(The contents of this English essay are very good, so afterwards [there is] just the issue of grammar and spelling...) (Matsui, 2001: 54)

The meaning of the first clause of the teacher's utterance (kono eibun essei, naiyoo totemo ii) directly expresses approval or encouragement of the hearer (that is, the teacher shows he or she thinks well of the student). The fact that the teacher shows she thinks well of her student is inferred by the student rather than being anticipated, because this kind of utterance is not conventionally used to show approval of someone (thereby giving rise to politeness). 
In further example in Japanese, Mari indirectly refuses Yoko's invitation to go to karaoke by giving a reason why she can't go, thereby implicating politeness.

(6) Yoko: Osoku na-tta kedo, karaoke yotte (i)ka-nai?

late become-Past but, karaoke drop in go-Negative?

(It's late, but do you want to go to karaoke?)

Mari: Ashita hachi-ji ni juuyoona kaigi ga

tomorrow eight o'clock at important meeting Nominative

hai-tte-iru no.

enter-Te-State Nominaliser

(I have an important meeting tomorrow at eight o'clock)

Yoko: Wakat-ta. Ja mata kondo to iu koto de.

understand-Past. Well again next time Quote say thing with

(Okay. Well next time then) (ibid: 56)

The politeness which arises in this example consists of assumptions such as Mari wa riyuu o nobete teinei ni sasoi o kotowatteiru ('Mari gave a reason and refused the invitation politely'), and Teinei ni kotowatteiru to iu koto wa shoorai tsugoo ga tsukeba issho ni karaoke ni itte mo ii to iu koto da ('Refusing politely indicates that when it is more convenient in the future, [Mari] may go together with me to karaoke') (ibid: 57). In other words, Mari shows that she does not think badly of Yoko in spite of refusing Yoko's invitation. The politeness that arises is inferred rather than being anticipated, because this implicature is not conventionalised for showing one does not think badly of someone else.

There are a number of other distinctions that have been previously drawn in politeness theory that might appear to be related to the distinction between anticipated and inferred politeness. In particular, Watts' $(1989,1992)$ notion of "politic behaviour" which encompasses polite behaviour, Ide's (1989) notions of "discernment politeness" and "volitional politeness", and Lee-Wong's (2000) notions of "normative politeness" and "strategic politeness". However, the focus of these concepts differs from that highlighted in the distinction between anticipated and inferred politeness.

Watts' $(1989,1992)$ suggests that politeness should be viewed in the wider context of "politic behaviour". The former is defined as marked behaviour that leads to an enhancement of one's standing with respect to others (that is, making other people have a better opinion of oneself) (Watts, 1992: 51), while the latter is defined as behaviour which establishes or maintains the state of equilibrium of 
personal relationships (ibid: 50). Watts' view of politeness, however, diverges somewhat from the distinction between anticipated and inferred politeness. Firstly, whether politeness is anticipated or inferred, the nature of what is communicated does not change. Both anticipated and inferred politeness involve showing that one thinks well of others, or not more highly of oneself than one should. Polite and politic behaviour, on the other hand, often involve communicating distinct kinds of interpersonal implications. Secondly, anticipated politeness does not encompass or overlap with inferred politeness. Politeness is either anticipated or it is inferred, while in Watts' view politeness is one species of politic behaviour, or at least overlaps with it.

The notions of discernment and volitional politeness (Ide, 1989), or the analogous notions of normative and strategic politeness (Lee-Wong, 2000), are closer in nature to the concepts of anticipated and inferred politeness. Discernment politeness involves speakers following social norms or conventions, while volitional politeness involves the intentional use by speakers of strategies to communicate politeness (Ide, 1989: 230-231).

However, there are at least two main differences between discernment/normative and volitional/strategic politeness, and anticipated and inferred politeness. First of all, whether politeness is anticipated or inferred, it still involves evaluations of what a person shows they think of someone else (or themselves) relative to what people should show they think of others or themselves. In other words, politeness always arises relative to social norms. Both anticipated and inferred politeness involve behaviour that falls within the appropriate range of behaviour as dictated by social norms. Secondly, anticipated and inferred politeness are firmly situated in the hearer's view of the interaction, while discernment/normative and volitional/strategic politeness are framed in terms of the speaker's perspective. Whether politeness is anticipated or inferred depends primarily on what the hearer expects the speaker will show he thinks of someone else or him/herself.

The distinction between anticipated and inferred politeness constitutes an important part of the relevance theoretic approach to politeness. Relevance theorists have argued that the 'principle of relevance' can be used to make this distinction. In the following section it is argued, however, that the notion of cognitive effects, which is central to the principle of relevance, needs to be more adequately characterised in relation to politeness if it is to provide a solid 
theoretical foundation for further developments of this important distinction.

\section{Relevance theory and anticipated versus inferred politeness}

Relevance theory is essentially a theory of utterance comprehension from the perspective of the hearer. Its core claim is that all communication is constrained by the 'principle of relevance'. The principle of relevance, or more specifically the communicative principle of relevance, states that "every act of ostensive communication communicates a presumption of its own optimal relevance" (Sperber and Wilson 1995: 260), where relevance is defined as a balance between (positive) cognitive effects and processing effort (pp.265-266).

Relevance theory has been criticised as an inherently asocial pragmatic theory (Mey and Talbot 1988), but others have countered that relevance theory can accommodate social aspects of communication (Jucker 1988; Coupland and Jaworski 1997; Sperber and Wilson 1997). A number of studies have attempted to apply relevance theory to the study of politeness (Escandell-Vidal 1996, 1998; Jary 1998a, 1998b; Matsui 2001; Zegarac, 1998, 2000), retaining Brown and Levinson's notion of 'face' as part of their explanations of politeness phenomena.

As was noted previously, a number of relevance theorists have argued that generally politeness is not intended to be communicated by interlocutors (that is, it is not inferred as Brown and Levinson claim), but rather is a matter of 'social adequacy' or conforming to a set of cultural norms (Escandell-Vidal 1996, 1998; Jary 1998a; Zegarac 1998). In other words, the cognitive effects arising from the use of many so-called 'polite forms' (such as Can you pass the salt?) are not relevant enough to be noticed by hearers, because they only confirm what hearers already think the speaker thinks of them, and consequently are not communicated.

"When I say to you: Do you mind if I open the window? I am certainly using a polite form. But am I communicating some polite assumptions? Hardly, provided you assume that I am generally a polite person. True, my utterance does provide evidence of my being polite, but you would not be justified in assuming that I intended it to be relevant in this way. An utterance can hardly be expected to be relevant to the hearer merely by virtue of confirming belief assumptions which are already held at maximal strength." (Zegarac 1998: 353: my emphasis)

Under this view, politeness is not inferred, because it arises from following social 
norms; and nothing is inferred through the adherence to these social norms, if the interlocutors involved usually follow these social norms (just as nothing in particular is inferred from producing grammatical utterances in most situations). In other words, the interpersonal cognitive effects arising from this kind of utterance are not sufficiently great to outweigh the processing costs involved, so they are not relevant enough to be inferred.

The relevance theoretic approach to politeness has been applied in examining honorifics and other related politeness phenomena in Japanese. Honorifics (sonkeigo and kenjoogo; 'subject' and 'object' honorifics), speech levels (keitai and jootai; 'polite forms' and 'non-polite forms'), and personal pronouns, which are often used according to social norms, are termed 'politeness indicators' by Matsui (2001: 55). She argues that politeness is not inferred as part of an explicature in the case of politeness indicators, as they do not contribute to the truth-conditional content of utterances. ${ }^{6}$ For example, there is no difference in the truth-conditions of Sensei ga kita ('the teacher came') and Sensei ga irasshaimashita ('the teacher came-Honorific'). She goes on to argue that politeness indicators do not explicate or implicate politeness at all. Since their use is based on the interlocutor's mutual cognitive environment (that is, they are used according to social norms), their occurrence does not have any effect on the hearer's cognitive environment. Instead, they lower processing effort, and thereby facilitate communication.

In drawing the distinction between anticipated and inferred politeness, relevance theorists claim that politeness can only be inferred when the assumption of politeness is 'relevant' enough. Whether an assumption is 'relevant' enough to be inferred depends on whether or not it has sufficiently large cognitive effects relative to processing effort. However, the problem facing the relevance theoretic account of the distinction between anticipated and inferred politeness is that neither cognitive effects nor processing effort (the two key components of Sperber and Wilson's technical notion of relevance) have been sufficiently characterised in relation to politeness. In particular, there is no distinction made between cognitive effects which have 'positive affect' (such as feelings of approval or warmth and so on), and those which have 'negative affect' (such as antagonism or alientation and so on). For example, there is no distinction made between showing one thinks well of others (which can give rise to politeness), and showing one thinks badly of others (which can give rise to impoliteness). 
Kuiper (1997) attempts to develop further develop the relevance theoretic notion of cognitive effects in relation to politeness in his proposals about 'face'. He conceptualises face as calibrations of basic assumptions about social selves created through interactions with others. The assumptions with which face are calibrated are "everyone loves me" through to "everybody hates me" (positive face), and "I can do anything" through to "I can't do anything" (negative face). However, these assumptions, while heading in the right direction, are too simplistic to capture the complexities of the assumptions about social selves underlying politeness. For example, showing one thinks well of others (which can give rise to politeness), involves more than just showing one approves of someone else (Kuiper's notion of positive face), or showing one thinks someone else is quite competent (Kuiper's notion of negative face). It can also involve recognition of someone else's social position, or respecting the right of others to be free from imposition.

The notion of cognitive effects which underlies the principle of relevance has not been sufficiently characterised in relation to politeness. It is thus difficult to see how the principle of relevance can be useful in furthering our understanding of the distinction between anticipated and inferred politeness. While relevance theorists have tried to refute the claim that relevance theory is essentially asocial, to date it has not provided a solid foundation upon which to theorize about social phenomena such as politeness.

However, there are alternative frameworks in which to examine the distinction between anticipated and inferred politeness. In the following section, the potential of discourse politeness theory for further investigation of this distinction is discussed.

\section{Discourse politeness theory and anticipated versus inferred politeness}

The importance of examining politeness not only at the utterance level, but also at the discourse level, has been emphasised by Usami, who is developing a discourse theory of politeness (1998, 2001a, 2001b, 2002). The two key proposals in discourse politeness theory are the interdependent notions of "discourse politeness" and "unmarked politeness".

The notion of discourse politeness is an attempt by Usami to integrate discourse level phenomena into politeness theory. Discourse politeness is defined by 
Usami (2001a) as follows:

"Discourse politeness is the functional dynamic as a whole of factors (including factors at the level of utterances) giving rise to 'pragmatic politeness', which cannot be observed at the level of single utterances, but rather only in longer stretches of discourse." (p.11)

In other words, discourse politeness is the "contribution of the discourse as a whole towards the regulation of politeness" (ibid: 9).

Usami goes on to suggest that discourse politeness is primarily realized as "unmarked politeness" in conversations. Unmarked politeness is essentially synonymous with the notion of anticipated politeness. Unmarked politeness is defined as follows:

"It is a type (of politeness) where certain language behaviour is unconsciously expected, and when it does not occur as expected and one becomes conscious of this, the utterance or discourse is taken to be impolite. In other words, it refers to neither particularly (marked) polite utterances, nor to impolite utterances, but rather refers to the state of the discourse as a whole. I term utterances contributing to the discourse as a whole which are not impolite and satisfy what is implicitly expected to occur according to each specific situation, 'unmarked behaviour'. 'Unmarked behaviour' becomes 'unmarked politeness' when politeness is involved." (ibid: 12)

For discourse politeness in each specific context there are 'defaults', both for discourse politeness as a whole, and for the individual factors which constitute discourse politeness, and these represent unmarked politeness in that conversation. On the other hand, linguistic behaviour which deviates from these defaults and shows concern for the interlocutor is termed "marked politeness". Marked politeness is equated with Brown and Levinson's implicated politeness by Usami (ibid: 11).

Usami (2001a, b) discusses the use of 'speech levels' in Japanese to illustrate the contrast between unmarked and marked politeness. ${ }^{8}$ She claims that the unmarked speech level for utterance-endings in conversations between people meeting for the first time is the 'polite form' (P), while the unmarked speech level for conversations between friends or housewives is the 'non-polite form' (N). The 'polite form' (keitai) is essentially the desu/masu form (e.g. ikimasu, 'to go'), while the 'non-polite form' (jootai) is the plain or dictionary form (e.g. $i k u$, 'to go'). These respective forms are unmarked when they are used more than $50 \%$ of the 
time in conversations, and constitute the unmarked discourse politeness defaults in their respective contexts. Thus in conversations between people meeting for the first time, the 'non-polite form' constitutes marked behaviour, while in conversations between housewives or friends, the 'polite form' represents marked behaviour.

There are three types of effects marked behaviour can give rise to:

(1) "marked politeness" (for example, the use of 'non-polite forms' in conversations between people meeting for the first time may show familiarity or closeness (that is, show the speaker approves of the addressee), while the use of 'polite forms' in conversations between friends may show the speaker's reluctance to impinge on the hearer (that is, show the speaker respects the addressee).

(2) "linguistic discourse effects" (for example, emphasising propositional content or topic changes).

(3) "minus politeness" (that is, impoliteness or sarcasm).

In order to identify marked politeness (and other effects such as impoliteness), it is therefore necessary to first establish what constitutes unmarked politeness in a particular conversation (Usami 2001a: 45).

Usami (2002) reports from her analysis of 72 conversations between unacquainted Japanese adults, that $60 \%$ of utterance-endings were the 'polite form', $10 \%$ were the 'non-polite form', and 30\% had no 'politeness marker' at all. The default ratio for speech levels in this context is therefore: 'polite form' 6: 'non-polite form' 1: no marker 3. The default speech level for conversations between unacquainted adults can thus be identified as the 'polite form'. In other words, the polite form constitutes 'unmarked politeness' in this context, and thus 'non-polite forms', in particular, are a form of marked behaviour (Usami 2001a: 32-33). ${ }^{9}$ Depending on the content and context of the utterance, this marked behaviour may give rise to 'marked politeness', impoliteness, or some kind of discourse effect such as marking a change in topic.

Determining discourse politeness defaults, which are fundamental for an analysis of unmarked and marked politeness in conversations, requires careful empirical analysis of conversations involving the element in question. These defaults vary not only for each element of discourse politeness (such as frequency of backchannels, frequency of topic introduction, utterance sequence patterns and so on), but may even vary for the same element within a single conversation. For example, in conversations between younger Japanese, it has been shown that 
while the 'polite form' is most common at the beginning of conversations, as time passes and the interlocutors become more comfortable with each other, the proportion of 'non-polite forms' increases (ibid: 33-34). Discourse politeness defaults may be different for speech levels depending on which part of the conversation is observed (that is, the beginning versus the end of the conversation), and thus what constitutes marked behaviour and what effects this marked behaviour gives rise to may also be different.

Discourse politeness defaults for honorifics have been established in Korean and Japanese by Kim (2000), who examined twelve conversations (six for each language) between unacquainted people in their twenties. Kim found that $30 \%$ of utterances contained 'super-polite forms' (that is, subject and object honorifics) in Korean, while only $10 \%$ of utterances contained 'super-polite forms' in Japanese. Thus politeness (or some other kind of effect) may be inferred in Korean if more than $30 \%$ of utterances in a conversation contain super-polite forms, while in Japanese conversations politeness may be inferred if only more than $10 \%$ of utterances contain super-polite forms.

Another example of discourse politeness defaults is that found by Xie (2001) in her study of utterance sequence patterns of requests in Chinese and Japanese. Her analysis of 120 conversations (60 for each language), which all involved a request to borrow some notes and handouts from a previous class at university from a close friend, showed a clear difference in the discourse politeness defaults for request utterance sequences. In Japanese, the discourse politeness default sequence was found to be an attention-getter (such as 'excuse me' or calling out the addressee's name), followed by checking potential for compliance, and then supportive moves (such as giving reasons for the request), before the request utterance itself. In Chinese, however, the discourse politeness default sequence was found to involve only an attention-getter followed by the request utterance. Thus in Chinese, the use of supportive moves in making a request would constitute marked behaviour in this context. Although it could be interpreted as a form of marked politeness (that is, showing one respects the addressee), it is more likely to be interpreted as expressing social distance and unfriendliness (ibid: 98).

\section{Conclusion}


The notion of anticipated politeness is firmly grounded in our expectations about how people will interact with others. Politeness is anticipated when we think someone will say or do something that shows they think well of us (or do not think more highly of themselves than they should), and that person does as we expect. In contrast, politeness is inferred when we do not think someone will say or do something that shows they think well of us (or do not think more highly of themselves than they should), yet that person still does it contrary to our expectations. Whether anticipated politeness should be regarded as more important or prevalent than inferred politeness is still to be resolved, but whatever the result of that debate, it is clear that the existence of this distinction counters Brown and Levinson's claim that politeness is always inferred as an implicature.

Relevance theorists have been instrumental in bringing the notion of anticipated politeness to the fore. However, relevance theory does not provide a solid foundation upon which to investigate this distinction, because cognitive effects (which are a key component of the notion of relevance) are not sufficiently characterised in relation to politeness.

Discourse politeness theory, on the other hand, constitutes a more useful basis for investigating the distinction between anticipated and inferred politeness. It shows that one way in which to investigate this distinction is to determine the defaults for different elements of conversation (such as speech levels or utterance sequence patterns), through careful analysis of the use of these elements in particular contexts across samples of speech by speakers of the language in question.

While our intuitions provide a starting point for the investigation of the expectations underlying anticipated and inferred politeness, careful analysis of the behaviour of a reasonable sample of speakers is also required to determine what behaviour we might expect in different situations. Empirical analysis to determine defaults also avoids the possibility of unwarranted distortion arising from the researcher's own individual perceptions and intuitions about these defaults. There thus remains much work yet to be done in the field of politeness research.

\section{References}

Alymursy, Ahmad and John Wilson

2001 Towards a definition of Egyptian complimenting. Multilingua 20: 
133-154.

Brown, Penelope

1995 Politeness strategies and the attribution of intentions: the case of Tzeltal irony. In Esther Goody (ed.), Social Intelligence and Interaction. Cambridge: Cambridge University Press, 153-174.

2001 Politeness and language. In Neil Smelser and Paul Baltes (eds.), International Encyclopedia of the Social and Behavioural Sciences, Volume 17. Oxford: Pergamon, 11620-11624.

Brown, Penelope and Stephen Levinson

1987 Politeness. Some Universals in Language Usage. Cambridge: Cambridge University Press.

Carston, Robyn

2000 Explicature and Semantics. UCL Working Papers in Linguistics 12, $1-44$.

Coupland, Nikolas and Adam Jaworski

1997 Relevance, accommodation and conversation: modeling the social dimension of communication. Multilingua 16, 233-258.

Eelen, Gino

2001 A critique of politeness theories. Manchester: St. Jerome.

Escandell-Vidal, Victoria

1996 Towards a cognitive approach to politeness. Language Sciences 18, 629-650.

1998 Politeness: a relevant issue for relevance theory. Revista Alicantina de Estudios Ingleses 11, 45-57.

Fraser, Bruce

1990 Perspectives on politeness. Journal of Pragmatics 14, 219-236.

1999 Pragmatics, politeness, and perlocutions. Paper presented at the International Symposium on Linguistic Politeness: Theoretical Approaches and Intercultural Perspective, Chulalongkorn University, Bangkok, Thailand.

Haugh, Michael

2002 The intuitive basis of implicature. Pragmatics 12, 2: 117-134.

Haugh, Michael and Carl Hinze

2003 A metalinguistic approach to deconstructing the concepts of 'face' and 'politeness' in Chinese, English and Japanese. Journal of Pragmatics 
35, 1581-1611.

Ide, Sachiko

1989 Formal forms and discernment: two neglected aspects of universals of linguistic politeness. Multilingua 8, 223-248.

Janney, Richard and Horst Arndt

1993 Universality and relativity in cross-cultural politeness research: a historical perspective. Multilingua 12: 13-50.

Jary, Mark

1998a Relevance theory and the communication of politeness. Journal of Pragmatics 30, 1-19.

1998b Is relevance theory asocial? Revista Alicantina de Estudios Ingleses 11, 157-169.

Jucker, Andreas

1988 The relevance of politeness. Multilingua 7, 375-384.

Kim, Jina

2000 Disukoosu poraitonesu no nichikan taishoo kenkyuu: supiichi reberu to supiichi reberu shifuto no kinoo ni kansuru koosatsu (Comparative research of discourse politeness in Japanese and Korean: Consideration of the functions of speech levels and speech level shift). Unpublished Masters thesis, Tokyo University of Foreign Studies.

Kuiper, Koenraad

1997 The relevance of face calibration. Paper presented at the University of Hertfordshire Relevance Theory Workshop, Chelmsford, United Kingdom.

Lee-Wong, Song Mei

2000 Politeness and face in Chinese culture. Bern: Peter Lang.

2002 Contextualising intercultural communication and sociopragmatic choices. Multilingua 21: 79-99.

Malinowski, Bronislaw

1923 The problem of meaning in primitive languages. In C. Ogden and I. Richards (eds.), The Meaning of Meaning. London: Routledge and Kegan Paul, 296-336.

Matsui, Tomoko

2001 Kanrensei riron kara mita poraitonesu (Politeness from the perspective of relevance theory). Gengo 30 (11), 52-59. 
Matsumoto, Yoshiko

1989 Politeness and conversational universals - observations from Japanese. Multilingua 8: 207-221.

Mey, Jacob and Mary Talbot

1988 Computation and the soul. Journal of Pragmatics 12, 743-789.

Nwoye, Onuigobo

1989 Linguistic politeness in Igbo. Multilingua 8, 259-275.

Pan, Yuling

2000 Politeness in Chinese face-to-face interaction. Stamford, CT: Ablex.

Selnick, Sharon

2002 Appropriate politeness in interactions with acquaintances and close friends: when is saying "thank you" going too far? Paper presented at the $52^{\text {nd }}$ International Communication Association conference, Seoul, Korea.

Sperber, Dan and Deirdre Wilson

1995 Relevance. Communication and cognition. Oxford: Blackwell.

1997 Remarks on relevance theory and the social sciences. Multilingua 16: $145-151$.

Terkourafi, Marina

2001a The distinction between generalised and particularised implicatures and linguistic politeness. Paper presented at the BI-DIALOG 2001. Fifth Workshop on the Semantics and Pragmatics of Dialogue, Bielefeld University, Germany.

2001b Politeness in Cypriot Greek: A frame-based approach. Unpublished $\mathrm{PhD}$ thesis, Cambridge University.

Usami, Mayumi

1998 Poraitonesu riron no tenkai: disukoosu poraitonesu to iu toraekata (Development of politeness theory: the concept of discourse politeness). Tokyo Gaikokugo Daigaku Nihon Kenkyuu Kyooiku Nenpoo 1997 Nendopan 3, 145-159.

2001a Danwa no poraitonesu - poraitonesu no danwa riron koosoo (Discourse politeness: Discourse theory of politeness - a preliminary framework. In Mutsuro Kai (ed.), Danwa no Poraitonesu (Discourse Politeness). Tokyo: The National Language Research Institute, 9-58. 
2001b Tainin komyunikeeshon no shakaishinrigaku - disukoosu poraitonesu to iu kanten kara (The social psychology of interpersonal communication - from the perspective of discourse politeness). Gengo 30 (6).

2002 Discourse Politeness in Japanese Conversation: Some Implications for a Universal Theory of Politeness. Tokyo: Hituzi Syobo.

Watts, Richard

1989 Relevance and relational work: linguistic politeness as politic behaviour. Multilingua 8: 131-166.

1992 Linguistic politeness and politic verbal behaviour: reconsidering claims for universality. In Richard Watts, Sachiko Ide and Konrad Ehlich (eds.), Politeness in Language. Studies in its History, Theory and Practice. Berlin: Mouton de Gruyter, 43-69.

Xie, Yun

2001 Danwa reberu kara mita 'iraihatsuwa' no kiridashikata - Nihonjin daigakusei dooshi to Chugokujin daigakusei dooshi no irai danwa kara (The placing of utterances at the discourse level - a contrastive study of pre-request usage in discourse between Chinese and Japanese). Tokyo Gaikokugo Daigaku Nihongo Kenkyuu Kyooiku Nenpoo 2000 nendo pan 5, 77-101.

Zegarac, Vladmir

1998 What is phatic communication? In Villy Rouchota and Andreas Jucker (eds.), Current issues in relevance theory. Amsterdam: John Benjamins, 327-361.

2000 Face and cognitive modularity. Paper presented at the 7th International Pragmatics Conference, Budapest, Hungary.

\footnotetext{
${ }^{1}$ Fraser (1999), for example, explicitly claims that politeness is only ever anticipated as a perlocutionary effect and is never communicated: "...politeness is not communicated, it is not an implicature, and the absence of communicated politeness should not be taken as a lack of polite attitude...in any normal conversation, politeness is the expected state of affairs, where what constitutes politeness is dictated by the relevant socio-cultural norm for that interaction. Participants note not when someone is being polite but rather when the speaker is violating this norm. On this view, politeness is not communicated but is a type of perlocutionary effect..."

${ }^{2}$ The view of politeness outlined in this section is based on the approach proposed by Haugh and Hinze (2002).
} 
${ }^{3}$ In a different context this utterance will be interpreted differently (e.g. between a husband and wife at home), and politeness will not be anticipated.

${ }^{4}$ Phatic communication is a term coined by Malinowski (1923), and involves utterances "...whose main implicit import has to do with the speaker's disposition towards establishing and/or maintaining a social relationship with the hearer" (Zegarac, 1998: 330), and where the fact that an utterance has been made is often of more importance than the content of the utterance itself.

${ }^{5}$ In other languages, this type of implied request may not give rise to politeness, since politeness is culture-sensitive (as noted in the previous section).

${ }^{6}$ An explicature is defined as "...a propositional form communicated by an utterance which is pragmatically constructed on the basis of the propositional schema or template (logical form) that the utterance encodes; its content is an amalgam of linguistically decoded material and pragmatically inferred material..." (Carston, 2000: 10). It is contrasted with the notion of implicature, which is defined as any other propositional form communicated by an utterance; its content consists of wholly pragmatically inferred matter (Carston, 2000: 10; Sperber \& Wilson 1995: 182).

${ }^{7}$ Pragmatic politeness refers to "language behaviour that functions to establish and maintain smooth interpersonal relationships' (Usami, 2001a: 10).

${ }^{8}$ In Japanese there are two basic speech levels in terms of utterance-endings, the 'polite form' and the 'non-polite form'.

${ }^{9}$ Non-marking of speech level may also give rise to particular effects, such as expressing closeness by avoiding 'marking' social distance with 'polite forms'. 